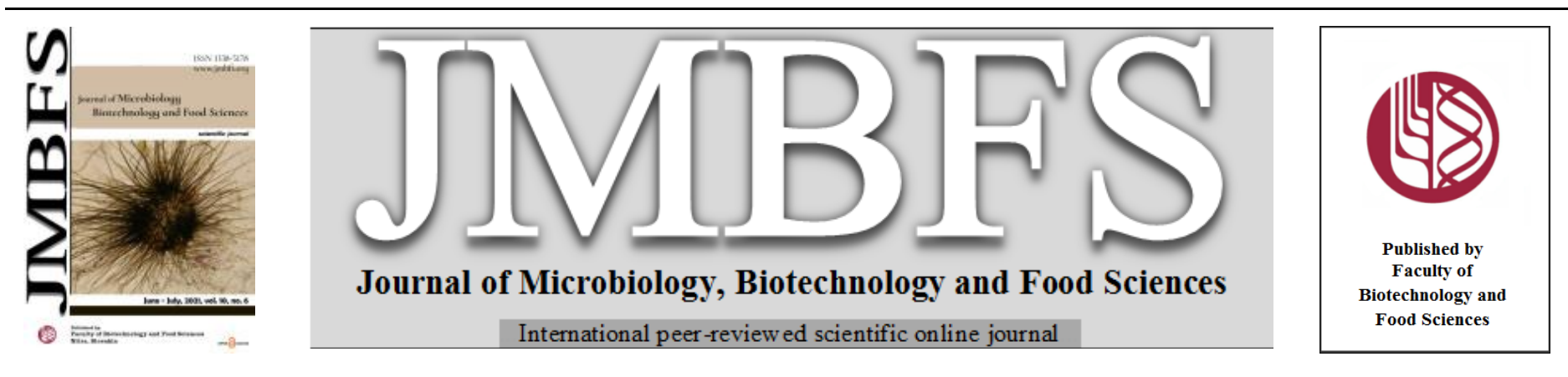

\title{
OPTIMIZATION OF OSMOTIC DEHYDRATION PROCESS OF CARAMBOLA (Averrhoacarambola L.) FRUIT IN BINARY SOLUTION OF SALT AND SUCROSE
}

\author{
Kshirod Kumar Dash ${ }^{1}$, Debashree Sen ${ }^{2}$, Dibyakanta Seth ${ }^{* 2,3}$ \\ $\operatorname{Address}(e s)$ : \\ ${ }^{1}$ Department of Food Technology, Ghani Khan Choudhury Institute of Engineering and Technology, Malda-732141,West Bengal, India. \\ ${ }^{2}$ Department of Food Engineering \& Technology, Tezpur University, Napam-784028, Tezpur, Assam, India. \\ ${ }^{3}$ Department of Food Process Engineering, National Institute of Technology, Rourkela-769008, Odisha, India, Ph.:+91-95087 15301.
}

*Corresponding author: dibya05@gmail.com

https://doi.org/10.15414/jmbfs.3307

ARTICLE INFO

Received 20. 6. 2020

Revised 13. 1. 2021

Accepted 20. 1.2021

Published 1. 6. 2021

Regular article

open $\partial_{\text {ACCESS }}$

\section{ABSTRACT}

The present work investigated the mass transfer process during osmotic dehydration of carambola fruit slice using binary solution of salt and sugar. The dehydration performance was improved by optimizing the time and temperature of dehydration, salt concentration and fruit to syrup ratio. Response Surface Methodology (RSM) was used to infer about the effects of these parameters on the rate of mass transfer such as water loss, solute gain, weight reduction and water activity of dehydrated carambola slice. A four factorial central composite rotatable design (CCD)adopting multiple regression technique was used to develop polynomial models of response variables and the adequacy of fit was ascertained by observing the correlation coefficients $\left(\mathrm{R}^{2}\right.$ values). All the independent variables significantly affected the response parameters within the selected range. Adopting desirability function, the optimized values of process variables were, salt concentration $15 \mathrm{~g} / 100 \mathrm{ml}$, temperature $45.08^{\circ} \mathrm{C}$, time $240 \mathrm{~min}$ and fruit to syrup ratio $1: 10$. The validation of the optimised parameters confirms invariability between the predicted and experimental results.

Keywords: Carambola, Osmotic dehydration , Binary solution, Response surface methodology

\section{INTRODUCTION}

Carambola or star fruit (Averrhoacarambola L.) is cultivated in many tropical and subtropical countries and belongs to the family Oxalidaceae. The fruit is a rich source of vitamin $\mathrm{C}$, antioxidants and phenolic compounds including some dietary fibre and potassium (Maharaj \& Badrie, 2006; Pantaleon-Velasco et al., 2014). The major antioxidants present in the fruit are $L$-ascorbic acid, epicatechin, gallic acid in gallotanin forms and pro-anthocyanidin (Gheewala $\boldsymbol{e t}$ al., 2012). Dasgupta et al. (2013) have extensively described the macroscopic structure, botanical origin, nutritional and functional properties of star fruit in their research.

Despite high nutritional values of carambola, its commercialization has not been so successful due to its fragility and high moisture content which results in a short shelf life. Modified atmosphere packaging has been studied extensively to extend the shelf life of whole star fruit for enhanced export potential (Ali et al., 2004). Drying is widely used to preserve fruits and vegetables and production of dehydrated products. Conventional drying methods like air drying drastically affect the nutritional as well as sensory qualities of the product(Ruiz-Lopez et al., 2010). Moreover, the energy consumption is high due to simultaneous heat and mass transfers involved (Fernandes et al., 2006). An alternative to conventional drying could be osmotic dehydration which is an energy efficient process and causes minimal nutrient loss due to low temperature treatment and since oxygen does not come in contact with the product the deteriorative effect is minimum (Karathanos et al., 1995). Osmotic dehydration involves concentration of food products by immersing in a hypertonic solution of salt, sugars, sorbitol or glycerol (Raoult-Wack et al., 1989). Counter-current mass diffusion of solute and moisture takes place across a semipermeable membrane such as the fruit surface during osmotic dehydration process. Solute flows from the osmotic solution into the fruit, concurrently moisture of fruit flows out through the semipermeable membrane such as tissue of the fruit to the osmotic medium, as a result the water activity of fruits reduces (Torreggiani, 1993). Osmotic pressure difference between the osmotic solution and the fruit tissue is the main driving force for mass diffusion across the fruit surface. The parameters like concentration and temperature of osmotic solution, the size and shape of the material, material to solution volume fraction and time and speed of agitation influence the diffusion rate in the process of osmosis (Raoult-Wack et al., 1989;
Rastogi et al., 1999; Rastogi \& Niranjan, 1998; Rastogi \& Raghavarao, 1997).

Limited works on osmotic dehydration of star fruit have been carried out by the research scientists. Ruiz-Lopez et al. (2010) emphasized the kinetics modeling of sugar diffusivity and concluded in their findings that among sucrose, fructose and glucose, sucrose was considered the best hypertonic solution. Roopa et al. (2014) demonstrated a combine effect of $70^{\circ}$ Brix sucrose solution at $48^{\circ} \mathrm{C}$ soaking temperature for 144 minute that exhibited good response in terms of solid gain and water loss.Campos et al. (2012) highlighted the effect of blanching on osmotically dehydrated carambola. Maharaj \& Badrie (2006) used sucrose and salt in osmotic dehydration of carambola, but not as binary solution. The synergistic effect of salt with sucrose solution on the osmo-dehydration characteristics of carambola has not yet been reported. Many researchers have discussed the synergistic effect of salt and sugar solution in different fruits and vegetables. Sugar solution forms an impermeable dilute solution film over the fruit surface during progress of soaking, thereby causing a decrease in diffusivity of water. Salt added in small quantity to sugar solution hinders the formation of impermeable film (İspir \& Toğrul, 2009; Lerici et al., 1985). Badwaik et al. (2013) have also used binary solution of sucrose and sodium chloride for osmotic dehydration of bamboo shoot. Hence, this piece of was carried out to optimize the osmotic dehydration of carambola slice using mixture of sucrose and sodium chloride osmotic solution.

\section{MATERIALS AND METHODS}

\section{Research materials}

The research materials constituted of Carambola fruit (Averrhoacarambola L.) collected from Tezpur University localities, Assam, India. The carambola fruit which was taken for experimentation was of sweet variety. The fruits were visually selected, at the fully ripen, almost maturity stage according to the color classification given by Abdullah et al. (2006). The fruits were stored at refrigeration temperature $\left(5^{\circ} \mathrm{C} \pm 1\right)$ before use for experimentation. The osmotic solutions were made using commercial sucrose and $\mathrm{NaCl}$ salt (Hi Media) with adequate amount of distilled water. The initial water activity of carambola fruit was $0.982 \pm 0.006$ and the initial moisture content was $86.15 \pm 1.08$. 


\section{Osmotic dehydration process}

The fruits, stored in refrigerator were tempered for half an hour and were cut into $8 \mathrm{~mm}$ slices, subjected to osmotic dehydration process maintaining varied conditions of temperature $\left(20-60^{\circ} \mathrm{C}\right)$, salt concentration $(0-20 \mathrm{~g} / 100 \mathrm{ml})$, time $(60$ $300 \mathrm{~min})$ and initial fruit to solution ratio(1:2.5-1:12.5) according to a complete 2 central composite rotatable design. The trials were taken in triplicate. The sugar concentration was kept constant at $50^{\circ}$ Brix as excess sucrose forms a surface crust on the substance while operating with high concentrations of sucrose above $50 \%$. The formed surface crust may also serve as a barrier for both diffusion of moisture and solute (Ferrari \& Hubinger, 2008). It is difficult to achieve higher sugar concentrations (concentration $>50 \%$ ) for osmotic dehydration process carried out at lower temperature such as $30^{\circ} \mathrm{C}$. In addition to this, at sucrose concentration above $50 \%$ the solution becomes viscous and difficult to stir (García-Toledo et al., 2016). The osmotic dehydration which is basically a batch process was carried out taking hypertonic solution and carambola fruit slices in $250 \mathrm{ml}$ Erlenmeyer flasks and the system was placed inside a temperature and agitation controlled incubator shaker (M/s Sartorius Stedian Biotech). Agitation of hypertonic solution helps in uniform distribution of mass concentration and prevents mass accumulation on the periphery of fruit surface. Possible evaporation from the osmotic solution was prevented by capping the Erlenmeyer flasks were during the osmo-dehydration process. As the process advances, layer of solution film forms at the interface of fruit and hypertonic solution which renders the diffusion drastically. So, the solution was agitated at a speed of 3.77 $\mathrm{g}^{\prime}$ to break the film formation. Agitation also helps in maintaining uniform concentration and temperature profile inside the osmotic solution. The carambola slices were taken out periodically from the osmotic solution as per experimental design (60-300 $\mathrm{min}$ ), drained, softly wiped with filter paper to remove surface moisture and weighed. Total solids content of the fresh and treated carambola cubes was determined by standard hot air oven method (AOAC, 2000). Water activity $\left(\mathrm{a}_{\mathrm{w}}\right)$ of the osmo-dehydrated carambola cubes was measured using AquaLab water activity meter. Experimental values are the mean of triplicate experiments.

\section{Mass transfer calculations}

Solute and water exchange between the osmotic solution and carambola cube during osmotic dehydration was assessed using water loss (WL), solute gain (SG) and weight reduction (WR). The osmo-dehydration parameters WL, SG and WR were calculated as per the following equations(Li et al., 2012):

$W L=\frac{\left(m_{i} x_{i}-m_{f} x_{f}\right) \times 100}{m_{f}}$

$$
\begin{aligned}
& S G=\frac{\left(m_{i} y_{i}-m_{f} y_{f}\right) \times 100}{m_{f}} \\
& W R=W L-S G
\end{aligned}
$$

where $m_{i}$ and $m_{f}$ are the initial and final weight (g) of the samples, respectively; $x_{i}$ and $x_{f}$ are the initial and final mass fraction of water (g water/g sample), respectively; $\mathrm{y}_{\mathrm{i}}$ and $\mathrm{y}_{\mathrm{f}}$ are the initial and final mass fraction of total solids ( $\mathrm{g}$ total solids/g sample), respectively (Singh et al., 2010).

\section{Experimental design and statistical analysis}

Response surface methodology, a statistical tool which is used to develop suitable mathematical relationship between the experimental variables and the obtained results, was used to find out the effects of process variables on WL, SG, WR and water activity $\left(\mathrm{a}_{\mathrm{w}}\right)$ during osmotic dehydration of carambola. Soaking time and temperature, salt concentration of hypertonic solution and fruit to syrup ratio were selected as independent variables. The range of temperature, time, concentration of salt and fruit to solution ratio selected were $20-60^{\circ} \mathrm{C}, 60$ $300 \mathrm{~min}, 0-20 \mathrm{~g} / 100 \mathrm{ml}$ and 1:2.5-1:12.5 respectively. On the other hand, sucrose concentration was fixed at $50^{\circ}$ Brix as referred from the work of (Singh et al. 2007). The temperature range and fruit to solution ratio was selected based on the work of (Campos $\boldsymbol{e t}$ al., 2012). Experimental design was accomplished using 2 rotatable factorial Central Composite Design (CCD). The four factors with five levels of each factor generated 30 experiments out of which 16 were factoria points, 8 axial points and 6 centre points. The repeated centre runs are important in the sense they helps in estimating the residual error and they are the measure of lack of fit of the fitted mathematical model (Seth \& Rajamanickam, 2012).

The axial points of factorial design helps in the estimation of curvature of the quadratic model. The generated experimental runs along with the corresponding results of dependent variables are shown in Table 1. Since, the exact nature of the true function(s) is either too complex or unknown, these functions were estimated by second order polynomials. The polynomial models were validated with a confidence level of $95 \%$ and the designs were fitted using least square method.

$$
\boldsymbol{y}_{\boldsymbol{h}}=\boldsymbol{\beta}_{\mathbf{0}}+\sum_{i=1}^{4} \boldsymbol{\beta}_{i} \boldsymbol{X}_{i}+\sum_{i=1}^{4} \boldsymbol{\beta}_{i i} \boldsymbol{X}_{i}^{2}+\sum_{i=1}^{3} \sum_{j=i+1}^{4} \boldsymbol{\beta}_{i j} \boldsymbol{X}_{i} \boldsymbol{X}_{j}+\boldsymbol{\epsilon}
$$

(4)

Where, $\beta_{0}$ is the constant, $\boldsymbol{\epsilon}$ is the residual (error) term, $\beta_{i}$ is the linear coefficient, $\beta_{i i}$ is the quadratic coefficient and $\beta_{i j}$ is the interaction coefficient, and $X_{\mathrm{i}}$ is the dimensionless coded factors. The values of regression coefficients of equation (4) are given in table 2 . The goodness of fit and significance of linear, quadratic and interaction effects of osmotic dehydration time, temperature, salt concentration and fruit to syrup ratio on WL, SG, WR and $\mathrm{a}_{\mathrm{w}}$ were examined using analysis of variance (ANOVA) (Table 2).

Table 1 Rotatable Central Composite design (coded and actual variables) for osmotic dehydration of carambola fruit and obtained

\begin{tabular}{|c|c|c|c|c|c|c|c|c|c|}
\hline & \multirow[t]{2}{*}{ Run } & \multicolumn{4}{|c|}{ Variables levels (coded/actual) } & \multicolumn{4}{|c|}{ Response parameters } \\
\hline & & $\begin{array}{l}\text { Time } \\
(\mathrm{min})\end{array}$ & $\begin{array}{l}\text { Temp } \\
\left({ }^{\circ} \mathrm{C}\right)\end{array}$ & $\begin{array}{l}\text { Salt conc. } \\
\text { (g/100ml) }\end{array}$ & $\begin{array}{l}\text { Fruit: } \\
\text { Syrup }\end{array}$ & $\begin{array}{l}\text { WL } \\
(\%)\end{array}$ & $\begin{array}{l}\text { SG } \\
(\%)\end{array}$ & $\begin{array}{l}\text { WR } \\
(\%)\end{array}$ & $a_{w}$ \\
\hline \multirow[t]{16}{*}{ Factorial points } & 1 & $+1(240)$ & $-1(30)$ & $+1(15)$ & $-1(5)$ & 63.38 & 18.53 & 43.84 & 0.83 \\
\hline & 2 & $+1(240)$ & $+1(50)$ & $+1(15)$ & $-1(5)$ & 68.19 & 15.73 & 52.46 & 0.76 \\
\hline & 3 & $-1(120)$ & $+1(50)$ & $+1(15)$ & $-1(5)$ & 64.93 & 17.84 & 47.09 & 0.83 \\
\hline & 4 & $-1(120)$ & $1(30)$ & $+1(15)$ & $+1(10)$ & 61.37 & 12.11 & 49.26 & 0.89 \\
\hline & 5 & $+1(240)$ & $1(30)$ & $+1(15)$ & $+1(10)$ & 65.70 & 12.78 & 52.92 & 0.82 \\
\hline & 6 & $-1(120)$ & $+1(50)$ & $-1(5)$ & $-1(5)$ & 60.54 & 10.38 & 50.16 & 0.89 \\
\hline & 7 & $-1(120)$ & $+1(50)$ & $+1(15)$ & $+1(10)$ & 65.70 & 17.07 & 48.63 & 0.83 \\
\hline & 8 & $+1(240)$ & $+1(50)$ & $-1(5)$ & $+1(10)$ & 63.88 & 17.12 & 46.76 & 0.80 \\
\hline & 9 & $+1(240)$ & $1(30)$ & $-1(5)$ & $-1(5)$ & 59.03 & 13.75 & 45.28 & 0.86 \\
\hline & 10 & $-1(120)$ & $1(30)$ & $-1(5)$ & $-1(5)$ & 56.15 & 12.46 & 43.69 & 0.87 \\
\hline & 11 & $+1(240)$ & $+1(50)$ & $-1(5)$ & $-1(5)$ & 61.83 & 12.11 & 49.72 & 0.85 \\
\hline & 12 & $+1(240)$ & $1(30)$ & $-1(5)$ & +1 (10) & 62.90 & 11.72 & 51.18 & 0.84 \\
\hline & 13 & $+1(240)$ & $+1(50)$ & $+1(15)$ & $+1(10)$ & 69.68 & 16.18 & 53.50 & 0.76 \\
\hline & 14 & $-1(120)$ & $+1(50)$ & $-1(5)$ & $+1(10)$ & 60.48 & 15.33 & 44.15 & 0.88 \\
\hline & 15 & $-1(120)$ & $1(30)$ & $-1(5)$ & $+1(10)$ & 57.78 & 10.37 & 47.41 & 0.87 \\
\hline & 16 & $-1(120)$ & $1(30)$ & $+1(15)$ & $-1(5)$ & 60.00 & 19.92 & 40.08 & 0.87 \\
\hline \multirow[t]{8}{*}{ Axial points } & 17 & $-\alpha(60)$ & $0(40)$ & $0(10)$ & $0(7.5)$ & 57.92 & 14.34 & 43.58 & 0.88 \\
\hline & 18 & $+\alpha(300)$ & $0(40)$ & $0(10)$ & $0(7.5)$ & 65.99 & 14.74 & 51.25 & 0.78 \\
\hline & 19 & $0(180)$ & $-\alpha(20)$ & $0(10)$ & $0(7.5)$ & 58.43 & 12.88 & 45.55 & 0.85 \\
\hline & 20 & $0(180)$ & $+\alpha(60)$ & $0(10)$ & $0(7.5)$ & 66.78 & 16.20 & 50.58 & 0.80 \\
\hline & 21 & $0(180)$ & $0(40)$ & $-\alpha(0)$ & $0(7.5)$ & 58.31 & 11.28 & 47.03 & 0.87 \\
\hline & 22 & $0(180)$ & $0(40)$ & $+\alpha(20)$ & $0(7.5)$ & 66.14 & 17.80 & 48.34 & 0.80 \\
\hline & 23 & $0(180)$ & $0(40)$ & $0(10)$ & $-\alpha(2.5)$ & 62.07 & 15.54 & 46.53 & 0.87 \\
\hline & 24 & $0(180)$ & $0(40)$ & $0(10)$ & $+\alpha(12.5)$ & 64.75 & 13.14 & 51.61 & 0.86 \\
\hline \multirow[t]{6}{*}{ Central points } & 25 & $0(180)$ & $0(40)$ & $0(10)$ & $0(7.5)$ & 63.22 & 14.54 & 48.68 & 0.85 \\
\hline & 26 & $0(180)$ & $0(40)$ & $0(10)$ & $0(7.5)$ & 62.33 & 14.82 & 47.51 & 0.84 \\
\hline & 27 & $0(180)$ & $0(40)$ & $0(10)$ & $0(7.5)$ & 62.22 & 14.91 & 47.31 & 0.85 \\
\hline & 28 & $0(180)$ & $0(40)$ & $0(10)$ & $0(7.5)$ & 63.49 & 14.03 & 49.46 & 0.83 \\
\hline & 29 & $0(180)$ & $0(40)$ & $0(10)$ & $0(7.5)$ & 62.60 & 14.32 & 48.28 & 0.85 \\
\hline & 30 & $0(180)$ & $0(40)$ & $0(10)$ & $0(7.5)$ & 63.49 & 14.40 & 49.09 & 0.84 \\
\hline
\end{tabular}
response variables 
In order to confirm the quadratic polynomial models generated for the response variables are not desecrated, all the experimental data were observed through the residual plots and it was ensured that the mathematical models demonstrated standard normal distribution (Fig. 1). The generation of response surface plots and statistical analysis was done using the statistical software Design Expert-7, trial version (Stat-ease Inc., Minneapolis, USA)

\section{RESULTS AND DISCUSSION}

\section{Fitting of models and diagnostic check}

Experimental results of response variables for different runs of osmotic dehydration using CCD are shown in Table 1. Analysis of variance was done for determining the effects of different factors on corresponding responses i.e. WL, $\mathrm{SG}, \mathrm{WR}$ and $\mathrm{a}_{\mathrm{w}}$. The regression analysis indicated that, for all responses the models were significant $(\mathrm{p}<0.001)$ and lack of fits were not significant $(\mathrm{p}>0.05)$. The goodness of fit of the developed quadratic model was evinced by higher correlation coefficient values $\left(\mathrm{R}^{2}>0.97\right)$ in case of all the responses. The response surface plots were generated for each of the fitted models as function of two variables, while keeping other two variables at their central points to visualize the interaction effects of the two factors on the response. Diagnostic plots of all the responses are presented in Fig.1 and from the analyses of residuals it was evident that data were randomly distributed around zero and there are no outliers.
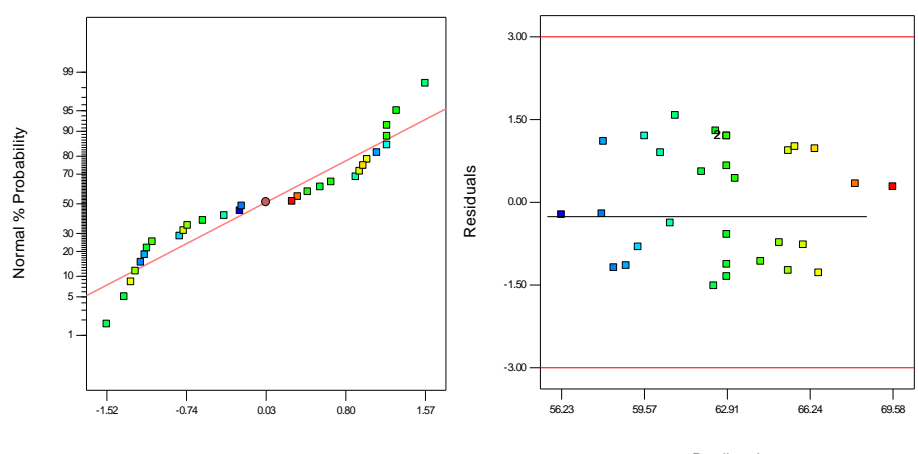

A
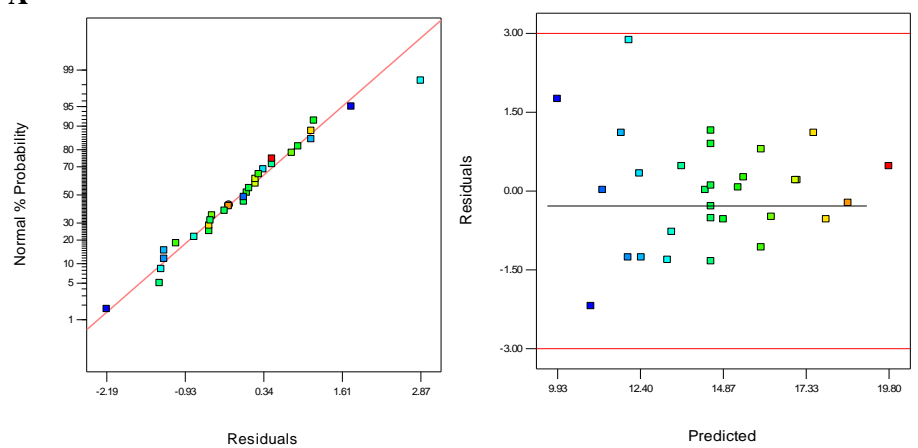

B

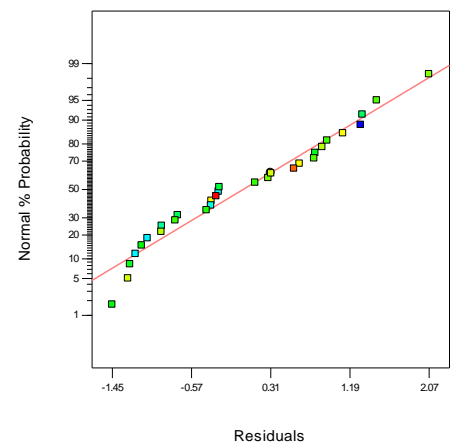

C
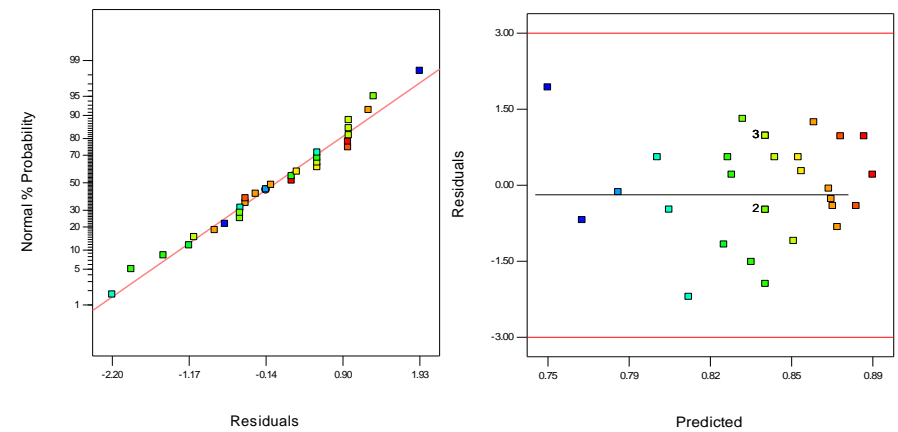

D

Figure 1 Normal probability and standard residual plots of the response variables; a) Water loss, b) Solute gain, c) Weight reduction and d) Water activity
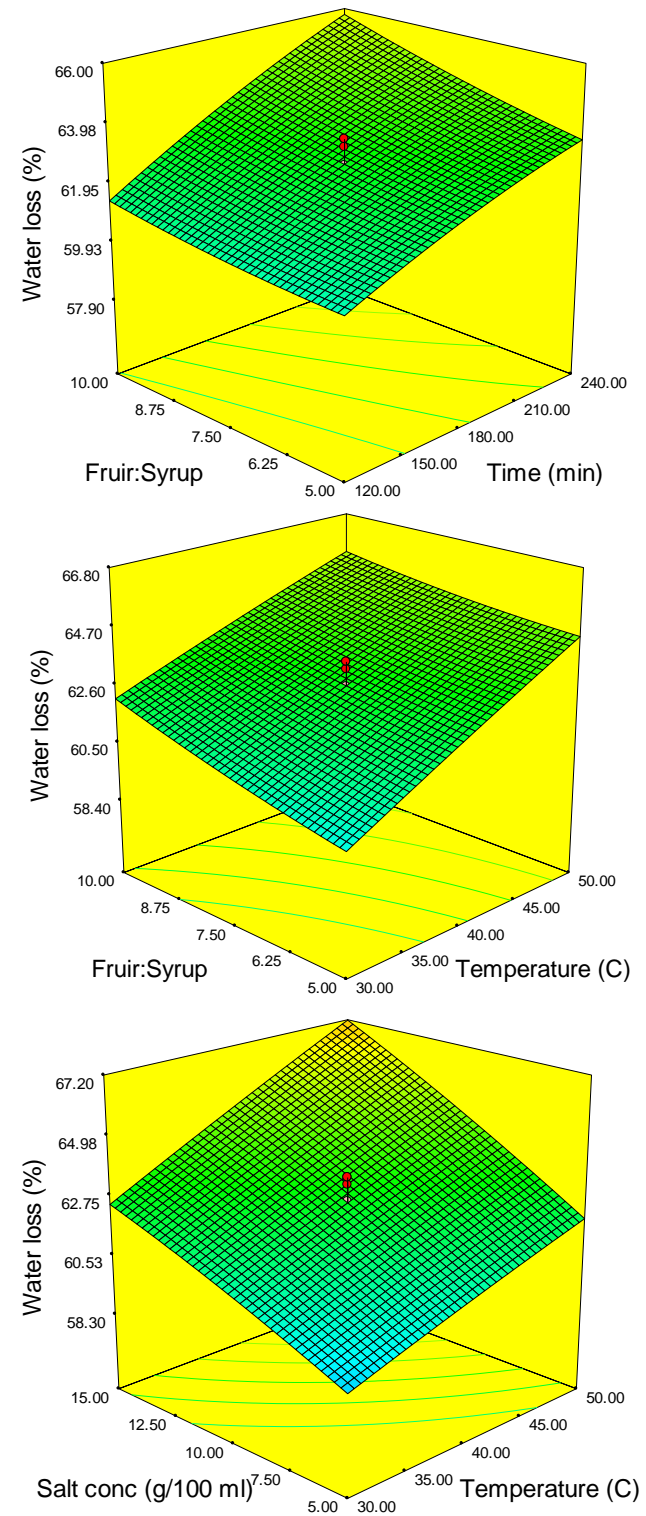

Figure 2 3D surface plots indicating interaction effects of independent variables on variation of water loss 
Table 2 ANOVA table of each response showing the linear, quadratic and interaction terms (calculated at coded values)

\begin{tabular}{|c|c|c|c|c|c|c|c|c|c|}
\hline \multirow{2}{*}{ Source } & \multirow{2}{*}{ DF } & \multicolumn{2}{|c|}{ WL } & \multicolumn{2}{|l|}{ SG } & \multicolumn{2}{|l|}{ WR } & \multicolumn{2}{|l|}{$\mathrm{a}_{\mathrm{w}}$} \\
\hline & & Coefficient & p-value & Coefficient & p-value & Coefficient & p-value & Coefficient & p-value \\
\hline Model & 14 & 62.89 & $<0.0001$ & 14.50 & $<0.0001$ & 48.20 & $<0.0001$ & 0.84 & $<0.0001$ \\
\hline \multicolumn{10}{|l|}{ Linear } \\
\hline Time $\left(\beta_{1}\right)$ & 1 & 1.82 & $<0.0001$ & 0.13 & 0.1086 & 1.68 & $<0.0001$ & -0.025 & $<0.0001$ \\
\hline Temperature $\left(\beta_{2}\right)$ & 1 & 1.90 & $<0.0001$ & 0.70 & $<0.0001$ & 0.95 & $<0.0001$ & -0.015 & $<0.0001$ \\
\hline Salt conc. $\left(\beta_{3}\right)$ & 1 & 2.17 & $<0.0001$ & 1.67 & $<0.0001$ & 0.50 & 0.0025 & -0.017 & $<0.0001$ \\
\hline Fruit:syrup $\left(\beta_{4}\right)$ & 1 & 0.78 & $<0.0001$ & -0.54 & $<0.0001$ & 1.40 & $<0.0001$ & -0.004 & 0.0243 \\
\hline \multicolumn{10}{|l|}{ Quadratic } \\
\hline$\beta_{1}^{2}$ & 1 & -0.23 & 0.0464 & 0.025 & 0.7361 & -0.20 & 0.1411 & -0.003 & 0.0535 \\
\hline$\beta_{2}^{2}$ & 1 & -0.064 & 0.5499 & 0.025 & 0.7361 & 0.089 & 0.4963 & -0.004 & 0.0096 \\
\hline$\beta_{3}{ }^{2}$ & 1 & -0.16 & 0.1485 & 0.025 & 0.7361 & -0.13 & 0.3215 & -0.002 & 0.2404 \\
\hline$\beta_{4}^{2}$ & 1 & 0.14 & 0.2069 & -0.025 & 0.7444 & 0.040 & 0.7566 & 0.006 & 0.0011 \\
\hline \multicolumn{10}{|l|}{ Interaction } \\
\hline$\beta_{1} \beta_{2}$ & 1 & -0.24 & 0.1039 & -0.087 & 0.3809 & -0.16 & 0.3594 & -0.007 & 0.0026 \\
\hline$\beta_{1} \beta_{3}$ & 1 & 0.14 & 0.3170 & -0.62 & $<0.0001$ & 0.75 & 0.0004 & -0.006 & 0.0103 \\
\hline$\beta_{1} \beta_{4}$ & 1 & 0.38 & 0.0147 & 0.21 & 0.0445 & 0.36 & 0.0457 & -0.006 & 0.0078 \\
\hline$\beta_{2} \beta_{3}$ & 1 & 0.45 & 0.0050 & -0.20 & 0.0596 & 0.64 & 0.0017 & -0.013 & $<0.0001$ \\
\hline$\beta_{2} \beta_{4}$ & 1 & -0.31 & 0.0389 & 1.71 & $<0.0001$ & -2.32 & $<0.0001$ & -0.003 & 0.1035 \\
\hline$\beta_{3} \beta_{4}$ & 1 & -0.096 & 0.4914 & -1.23 & $<0.0001$ & 1.46 & $<0.0001$ & 0.006 & 0.0103 \\
\hline Residual & 15 & & & & & & & & \\
\hline Lack of fit & 10 & & 0.6241 & & 0.3135 & & 0.7941 & & 0.6650 \\
\hline Pure error & 5 & & & & & & & & \\
\hline Total & 29 & & & & & & & & \\
\hline $\mathrm{R}^{2}$ & & 0.9856 & & 0.9864 & & 0.9768 & & 0.9764 & \\
\hline Adj- $R^{2}$ & & 0.9721 & & 0.9738 & & 0.9551 & & 0.9543 & \\
\hline $\mathrm{CV}$ & & 0.87 & & 2.67 & & 1.39 & & 0.89 & \\
\hline $\begin{array}{l}\text { Adequate } \\
\text { precision }\end{array}$ & & 34.591 & & 36.003 & & 32.861 & & 26.091 & \\
\hline
\end{tabular}

\section{Water loss}

ANOVA results for water loss shows that there was minimum coefficient of variation that indicates goodness of fit of the quadratic model $\left(R^{2}=0.98\right)$. The linear terms of all the independent variables of the quadratic model showed significant effect on water loss $(\mathrm{p}<0.001)$ whereas, only soaking time affected $\mathrm{WL}$ in quadratic term $(\mathrm{p}<0.046)$ (Table 2). The WL varied from 56.15 to $69.68 \%$ for different experimental runs. The relative magnitude of correlation coefficient values indicated maximum positive effect of salt concentration $(\beta=2.17)$ followed by temperature $(\beta=1.90)$ and process duration $(\beta=1.82)$. Similar effects were observed during osmotic dehydration of carrot cubes (Singh et al., 2010). Highest effect of binary salt solution concentration on WL could be due to higher trans-membrane difference of osmotic pressure which leads to higher water loss from the fruit tissue to the osmotic solution. Furthermore, the water loss is more due to increased permeability of cell membrane at higher temperature. Fig. 2 shows the three-dimensional response surface plots of the interaction effects of independent variables of time, temperature, salt concentration and fruit to syrup ratio on water loss of dehydrated carambola.

The effect of each interaction of process variables on the WL can be analyzed in these surface plots. Among all interactions, temperature and salt concentration exhibited highest significant positive effect on WL. Several research findings on osmotic dehydration of various food materials in the past support our findings (Eren \& Ertekin, 2007; Mayor et al., 2006; Park et al., 2002). The increase in water loss is due to synergistic effect of sucrose and salt concentration which is in agreement with the findings of Ozen $\boldsymbol{e t}$ al. (2002). In products like aonla slices, carrot cubes and papaya cubes also, sucrose concentration shows maximum positive effect on water loss (Shafiq et al., 2010). Solute concentration containing binary solution of sucrose and $\mathrm{NaCl}$ showed maximum effect on WL in case of carrot cubes and papaya (Fernandes et al., 2006; Singh et al., 2010).

\section{Solute gain}

The osmotic dehydration process variables temperature, salt concentration and fruit to syrup ratio significantly affected the solute gain $(\mathrm{P}<0.001)$ whereas, the duration of osmosis did not show any effect in linear terms. The positive relationship of temperature and salt concentration indicates that the solute gain is increased by the increase in temperature and salt concentration; salt concentration relatively affected more to solute gain. The higher rate of solute gain at higher salt concentration is attributed due to the higher trans-membrane pressure on the fruit surface and solution boundary. Moreover, the molecular weight of sugar plays a vital role in solute gain; lower molecular weight sugars favours better in terms of solute gain.
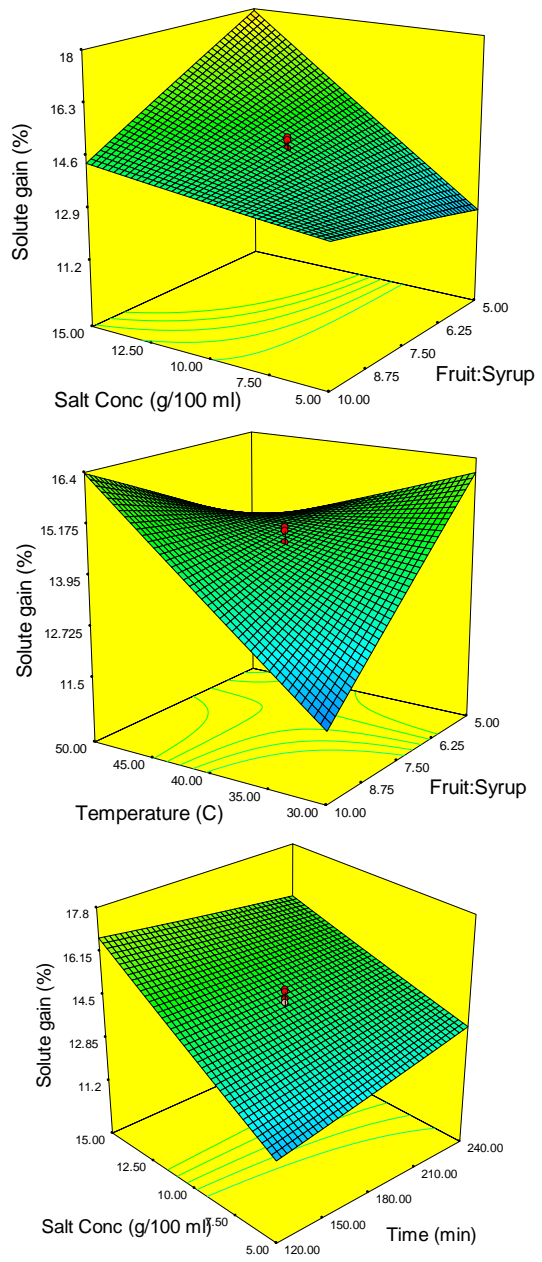

Figure 3 3D surface plots indicating interaction effects of independent variables on variation of solute gain 
The fruit to syrup ratio negatively affected the solute gain. This could be due to increased surface area per unit volume of osmotic solution. There is no quadratic correlation between the variables and solute gain (Table 2). The interaction effects of all combinations except time with temperature are significant and the interaction effects can be observed in the response surface plots (Fig.3)

With simultaneous increase of temperature and fruit to syrup ratio solute gain increased to certain extent and then decreased. Whereas the combined effect of salt concentration and fruit to syrup ratio was most influential factor that increased the solute gain. The solute gain varied from 10.37 to $19.92 \%$ among different experimental runs. The $R^{2}$ value of $98.64 \%$ confirms adequacy of the fitted model in describing the effect of process variables on solute gain. The coefficients of the developed equation are presented in table 2. Eren and Ertekin (2007) also reported similar findings during osmotic dehydration of potato slice. Quite a few research on osmotic dehydration of fruits confirm that solute concentration and temperature has significant positive effect on solid gain (Jokic et al., 2005; Ozdemir et al., 2008; Park et al., 2002). The typica characteristics of ionization and low molecular weight of salt makes it easier to pass through cell membrane and increase the water loss and solid gain (Eren $\&$ Ertekin, 2007; Mayor et al., 2006)

\section{Weight reduction}

Analysis of variance was carried out for weight reduction and is shown in Table 2. The correlation coefficient $\mathrm{R}^{2}$ value of 0.9768 implies that $97.68 \%$ of the experimental data showed compatibility with the data predicted by the polynomial model. The model coefficients are presented in Table 2. It was observed that all the independent variables significantly affected the weigh reduction in linear terms $(\mathrm{p}<0.01)$ whereas, they did not show any effect in quadratic term. The duration of process was the most influential factor among the variables followed by fruit to syrup ratio, temperature and salt concentration. The interaction effects of all combinations exhibited significant effect except time temperature combination. Temperature and fruit to syrup ratio in combination increased the weight reduction initially and then reduced at higher levels. The salt concentration and fruit to syrup ratio positively affected the weight reduction value. The interaction effects can also be observed in the response surface plot (Fig. 4).The findings are well supported by the work of Uddin et al. (2004) in which it was demonstrated that the weight reduction of carrot slices were affected linearly with sucrose concentration followed by immersion time. Similar results were also found with potato cubes in which weight reduction show positive correlation with time (Eren \& Ertekin, 2007). The weight reduction values are influenced by the values of WL and SG since it is the subtraction of these two parameters.
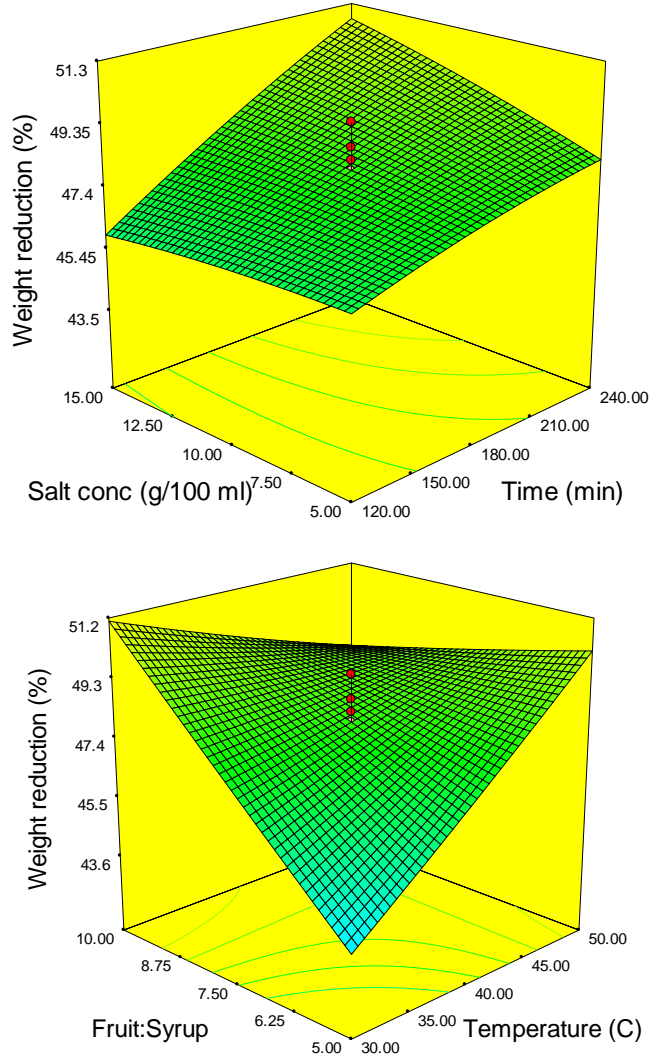

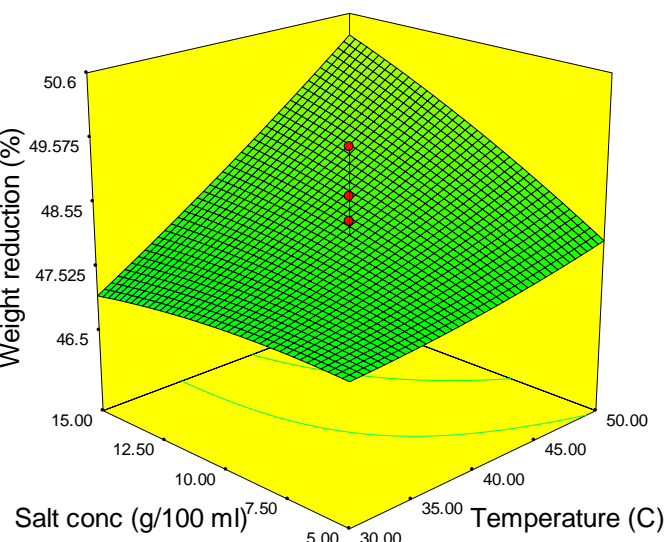

Figure 4 3D surface plots indicating interaction effects of independent variables on variation of weight reduction

\section{Water activity}

Table 2 shows the ANOVA results for water activity. The model has been found to be significant whereas the lack of fit has been found insignificant. A high correlation coefficient $\mathrm{R}^{2}$ of $97.64 \%$ evinced the adequacy of the selected quadratic model. From the findings it is evident that all the independent variables exhibited significant effect on water activity at all linear, quadratic and interaction terms except a few. The response surface plots of water activity are presented in Fig. 5. The water activity decreased with the increase in duration and temperature of osmotic dehydration as well as the salt concentration and fruit to syrup ratio. The water activity was maximum at the extreme levels of fruit to syrup ratio whereas salt concentration reduced the water activity. The water activity of dehydrated carambola is observed to be dependent on the overall weight reduction and water loss. Similar findings are also reported in osmotic dehydration of carambola (Campos et al., 2012). It has been found in case of potato slices that salt concentration has highest effect on reducing water activity followed by time (Eren \& Ertekin, 2007) whereas in the present work, duration of dehydration showed highest effect followed by temperature and salt concentration.
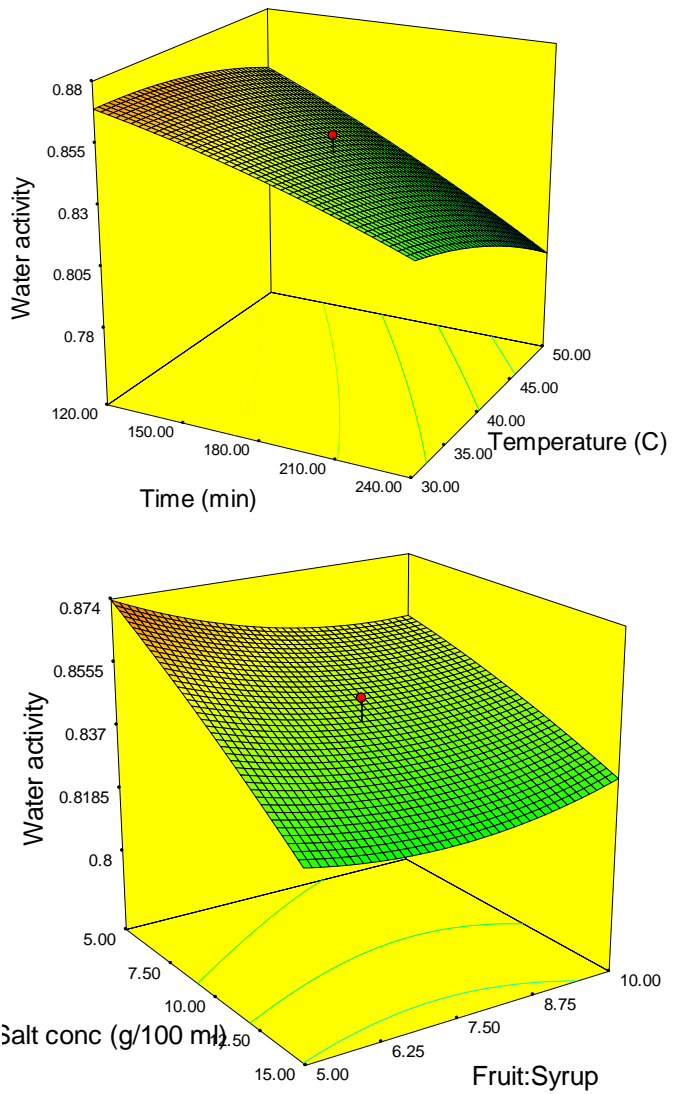


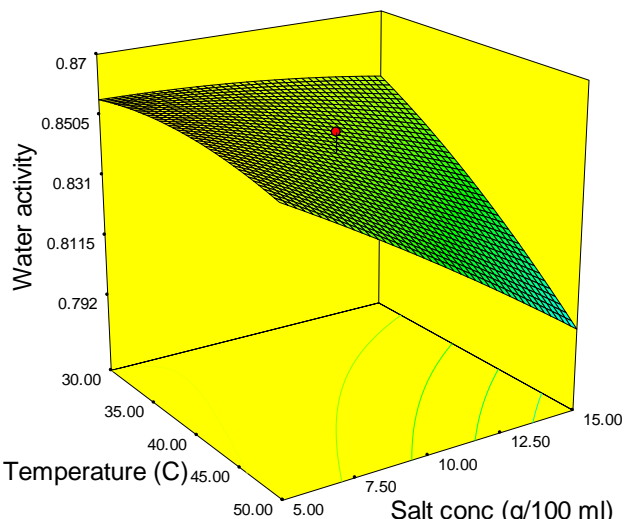

Figure 5 3D surface plots indicating interaction effects of independent variables on variation of water activity

\section{Optimization of osmotic dehydration of carambola}

In order to maximize the water loss as well as weight reduction, the concentration of solute and temperature of osmotic dehydration process should be higher, but at this condition solid gain also increases which is not desirable. When solute concentration and temperature are decreased then the processing time increases and the process becomes very slow (Raoultwack, 1994). So, the process parameters must be optimized to get the desired output. The optimization of process variables was done using Design-Expert software following numerical methods (Seth et al. 2017). The optimized value for time, temperature, solute concentration and fruit: syrup ratio has been found to be $240 \mathrm{~min} ., 45.08{ }^{\circ} \mathrm{C}, 15 \%$ and $1: 10$ respectively with a desirability value of 0.821 . The predicted response values in the optimized condition were WL $68.74 \%$, SG $15.24 \%, \mathrm{a}_{\mathrm{w}} 0.77$ and WR $53.63 \%$.

\section{Validation of the optimized process variables}

Validation of the optimized results was carried out to find its effectiveness Experiments were conducted at the optimized level of independent variables and mean values of the responses were compared with the corresponding model values to check the significant differences between them. Five experiments were conducted at optimum values of independent variables i.e. in a combination of time, temperature, solute concentration and fruit: syrup ratio of $240 \mathrm{~min}, 46.49$ ${ }^{\circ} \mathrm{C}, 15 \%$ and $1: 10$, respectively. The percentage relative deviation were found to be $0.13 \%, 0.39 \%, 3.04 \%$ and $0.88 \%$ for time, temperature, solute concentration and fruit: syrup ratio respectively.

\section{CONCLUSION}

Osmotic dehydration of carambola fruit using binary solution was more effective and this process can be encouraged for practical application. Four process parameters under different conditions of duration (60-300 min), temperature (20$\left.60^{\circ} \mathrm{C}\right)$, salt concentration $(0-20 \mathrm{~g} / 100 \mathrm{ml})$, and initial fruit to syrup ratio $(1: 2.5$ $1: 12.5)$ were taken for osmotic dehydration at constant agitation. Various responses viz. water loss, solute gain, weight reduction and water activity were studied. A $2^{4}$ central composite design was adopted for carambola cubes for experimentation. For each response, quadratic models were developed by using multiple linear regression analysis and the diagnostic tests performed exhibited normal distribution of data. Adequacy of the fitted models was checked by performing analysis of variance. The optimized value for time, temperature, solute concentration and fruit: syrup ratio was found to be $240 \mathrm{~min} ., 45.08^{\circ} \mathrm{C}$, $15 \%$ and 1:10 respectively. Percent relative deviations showed non-significant differences between the actual and predicted values.

Acknowledgement: The authors thanks to Tezpur University, Tezpur, Assam for providing the Laboratory facilities to carry out the works.

\section{REFERENCES}

Abdullah, M.Z., Mohamad-Saleh, J., Fathinul-Syahir, A.S., \& Mohdazemi, B.M.N. (2006). Discrimination and classification of fresh-cut star fruits (Averrhoa carambola L.) using automated machine vision system. Journal of Food Engineering, 76, 506-523.https://doi.org/10.1016/j.jfoodeng.2005.05.053 Ali, Z.M., Chin, L., Marimuthu, M., \& Lazan, H. (2004). Low temperature storage and modified atmospheric packaging of carambola fruit and their effects on ripening related texture changes, wall modification and chilling injury symptoms. Postharvest Biology and Technology, 33(2), 181-192. https://dx.doi.org/10.1016/j.postharvbio.2004.02.007

AOAC. (2000). Official methods of analysis (17th ed.): Gaithersburg, Maryland.

Badwaik, L.S., Choudhury, S., Borah, P.K., \& Deka, S.C. (2013). Optimization of Osmotic Dehydration Process of Bamboo Shoots in Mixtures of Sucrose and
Sodium Chloride Solutions. Journal of Food Processing and Preservation, 37 1068-1077. https://doi.org/10.1111/jfpp.12186

Campos, C.D.M., Sato, A.C.K., Tonon, R.V., Hubinger, M.D., \& Cunha, R.L. (2012). Effect of process variables on the osmotic dehydration of star-fruit slices. Ciência e Tecnologia de Alimentos, 32, 357-365. https://doi.org/10.1590/S010120612012005000034

Dasgupta, P., Chakraborty, P., \& Bala, N.N. (2013). Averrhoa carambola: An updated review. International Journal of Pharmacology Research and Review, 2, 54-63.

Eren, I., \& Ertekin, F.K. (2007). Optimization of osmotic dehydration of potato using response surface methodology. Journal of Food Engineering, 79, 344 352. http://dx.doi.org/10.1016/j.jfoodeng.2006.01.069

Fernandes, F.A.N., Rodrigues, S., Gaspareto, O.C.P., \& Oliveira, E.L. (2006) Optimization of osmotic dehydration of papaya followed by air-drying. Food Research International, 39, 498.https://doi.org/10.1016/j.foodres.2005.10.004

Ferrari, C.C., \& Hubinger, M.D. (2008). Evaluation of the mechanical properties and diffusion coefficients of osmodehydrated melon cubes. International Journal of Food Science \& Technology, 43, 20652074.https://doi.org/10.1111/j.1365-2621.2008.01824.x

García-Toledo, J. A., Ruiz-López, I. I., Martínez-Sánchez, C. E., RodríguezMiranda, J., Carmona-García, R., Torruco-Uco, J. G., ... \& Herman-Lara, E. (2016). Effect of osmotic dehydration on the physical and chemical properties of Mexican ginger (Zingiber officinale var. Grand Cayman). CyTA-Journal of Food, 14, 27-34.https://doi.org/10.1080/19476337.2015.1039068

Gheewala, P., Kalaria, P., Chakraborty, M., \& Kamath, J.V. (2012) Phytochemical and pharmacological profile of Averrhoa carambola Linn: An overview. International Research Journal of Pharmacy, 3, 88-92. http://dx.doi.org/10.7897/2230-8407

İspir, A., \& Toğrul, İ.T. (2009). The influence of application of pretreatment on the osmotic dehydration of apricots. Journal of Food Processing and Preservation, 33, 58-74. https://doi.org/10.1111/j.1745-4549.2008.00251.x

Jokic, A., Gyura, J., Ljubinko, L.L., \& Zavargo, Z. (2005). Osmotic dehydration of sugar beet in combined aqueous solutions of sucrose and sodium chloride. $\begin{array}{llll}\text { Journal of Food } \quad \text { Engineering, } & 78, & \text { 47-51. }\end{array}$ http://dx.doi.org/10.1016/j.jfoodeng.2005.09.003

Karathanos, V.T., Kostarapoulos, A.E., \& Saravacos, G.D. (1995). Air drying kinetics of osmotically dehydrated fruits. Drying Technology, 13, 1503-1521. http://dx.doi.org/10.1080/07373939508917036

Lerici, C.L., Pinnavaia, G., Dalla-Rosa, M., \& Bartolucci, L. (1985). Osmotic dehydration of fruits: Influence of osmotic agents on drying behavior and product quality. Journal of Food Science, 50, 1217-1219. http://dx.doi.org/10.1111/j.1365-2621.1985.tb10445.x

Li, H., Zhao, C., Guo, Y, An, K., Ding, S., \& Wang, Z. (2012). Mass transfer evaluation of ultrasonic osmotic dehydration of cherry tomatoes in sucrose and salt solutions. International Journal of Food Science and Technology, 47, 954960.http://dx.doi.org/10.1111/j.1365-2621.2011.02927.x

Maharaj, L.K., \& Badrie, N. (2006). Consumer acceptance and physicochemical quality of osmodehydrated carambola (Averrhoa carambola L.) slices. International Journal of Consumer Studies, 30, 16 24. https://doi.org/10.1111/j.1470-6431.2005.00428.x

Mayor, L., Moreira, R., Chenlo, F., \& Sereno, A. M. (2006). Kinetics of osmotic dehydration of pumpkin with sodium chloride solutions. Journal of Food Engineering, 74(2), 253-262. http://dx.doi.org/10.1016/j.jfoodeng.2005.03.003

Ozdemir, M., Ozen, B. F., Dock, L. L., \& Floros, J. D. (2008). Optimization of osmotic dehydration of diced green peppers by response surface methodology. LWT-Food Science and Technology, 41(10), 2044-2050. http://dx.doi.org/10.1016/j.lwt.2008.01.010

Ozen, B. F., Dock, L. L., Ozdemir, M., \& Floros, J. D. (2002). Processing factors affecting the osmotic dehydration of diced green peppers. International Journal of Food Science and Technology, 37(5), 497-502. http://dx.doi.org/10.1046/j.1365-2621.2002.00606.x

Pantaleon-Velasco, M. D., Ruiz-Lopez, I. I., Perez-Silva, A., Bravo-Clemente, L., Mateos, R., Ruiz-Espinosa, H., \& Vivar-Vera, M. D. (2014). Antioxidant and functional properties of a high dietary fibre powder from carambola (Averrhoa carambola L.) pomace. International Journal of Food Science and Technology, 49(9), 2101-2110. http://dx.doi.org/10.1111/ijfs.12519

Park, K. J., Bin, A., Brod, F. P. R., \& Park, T. H. K. B. (2002). Osmotic dehydration kinetics of pear D'anjou (Pyrus communis L.). Journal of Food Engineering, 52(3), 293-298. http://dx.doi.org/10.1016/S0260-8774(01)00118-2 Raoult-Wack, A, L., Lafont, F., Rios, G., \& Guilbert, S. (Eds.). (1989). Osmotic dehydration. Study of mass transfer in terms of engineering properties. New York, USA: Hemisphere Publishing.

Raoultwack, A. L. (1994). Recent Advances in the Osmotic Dehydration of Foods. Trends in Food Science \& Technology, 5(8), 255-260. http://dx.doi.org/10.1016/0924-2244(94)90018-3

Rastogi, N. K., Eshtiaghi, M. N., \& Knorr, D. (1999). Accelerated mass transfer during osmotic dehydration of high intensity electrical field pulse pretreated $\begin{array}{llll}\text { carrots. Journal of Food Science, 64(6), 1020-1023. } & \end{array}$ http://dx.doi.org/10.1111/j.1365-2621.1999.tb12272.x 
Rastogi, N. K., \& Niranjan, K. (1998). Enhanced mass transfer during osmotic dehydration of high pressure treated pineapple. Journal of Food Science, 63(3), 508-511. http://dx.doi.org/10.1111/j.1365-2621.1998.tb15774.x

Rastogi, N. K., \& Raghavarao, K. S. M. S. (1997). Water and solute diffusion coefficients of carrot as a function of temperature and concentration during osmotic dehydration. Journal of Food Engineering, 34(4), 429440.http://dx.doi.org/10.1016/S0260-8774(98)80034-4

Roopa, N., Chauhan, O. P., Raju, P. S., Gupta, D. K., Singh, R. K. R., \& Bawa, A. S. (2014). Process optimization for osmo-dehydrated carambola (Averrhoa carambola L) slices and its storage studies. Journal of Food Science and Technology-Mysore, 51(10), 2472-2480. http://dx.doi.org/10.1007/s13197-0120756-2

Ruiz-Lopez, I. I., Huerta-Mora, I. R., Vivar-Vera, M. A., Martinez-Sanchez, C. E., \& Herman-Lara, E. (2010). Effect of Osmotic Dehydration on Air-Drying Characteristics of Chayote. Drying Technology, 28(10), 1201-1212. http://dx.doi.org/10.1080/07373937.2010.482716

Seth, D., Mishra, H.N., \& Deka, S.C. (2017). Effect of spray drying process conditions on bacteria survival and acetaldehyde retention in sweetened yoghurt powder: An optimization study. Journal of Food Process Engineering, 40, e12487. https://doi/abs/10.1111/jfpe. 12487

Seth, D., \& Rajamanickam, G. (2012). Development of extruded snacks using soy, sorghum, millet and rice blend - A response surface methodology approach International Journal of Food Science and Technology, 47(7), 1526-1531. http://dx.doi.org/10.1111/j.1365-2621.2012.03001.x

Shafiq, A. M., Amarjit, S., \& Sawhney, B. K. (2010). Response surface optimization of osmotic dehydration process for aonla slices. Journal of Food Science and Technology-Mysore, 47(1), 47-54. https://doi.org/10.1007/s13197010-0014-4

Singh, B., Kumar, A., \& Gupta, A. K. (2007). Study of mass transfer kinetics and effective diffusivity during osmotic dehydration of carrot cubes. Journal of Food Engineering, 79(2), 471-480. http://dx.doi.org/10.1016/j.jfoodeng.2006.01.074

Singh, B., Panesar, P. S., Nanda, V., \& Kennedy, J. F. (2010). Optimisation of osmotic dehydration process of carrot cubes in mixtures of sucrose and sodium chloride solutions. Food Chemistry, 123(3), 590-600. http://dx.doi.org/10.1016/j.foodchem.2010.04.075

Torreggiani, D. (1993). Osmotic Dehydration in Fruit and Vegetable Processing. Food Research International, 26(1), 59-68. http://dx.doi.org/10.1016/0963 9969(93)90106-S

Uddin, M. B., Ainsworth, P., \& Ibanoglu, S. (2004). Evaluation of mass exchange during osmotic dehydration of carrots using response surface methodology. Journal of Food Engineering, 65(4), 473-477. http://dx.doi.org/10.1016/j.jfoodeng.2004.02.007 